Journal of Educational Technology

\& Online Learning

Volume 3 | Issue 3 | 2020

https://dergipark.org.tr/tr/pub/jetol

\title{
A Simulation-Based Interactive Learning Multimedia Development for Photosynthesis and Respiration Practicum in Junior High Schools
}

\author{
Putri PUTRİ ${ }^{\mathrm{a}}$ \\ Herminarto SOFYAN ${ }^{b}$ \\ a Putriaja925@gmail.com, Indonesia; ORCID: 0000-0003-4626-3319 \\ b herminsuny@gmail.com, Yogyakarta State University, Indonesia; ORCID: 0000-0003-0006-2423
}

Doi: $10.31681 /$ jetol. 775947

Suggested citation: Putri, P. \& Sofyan, H. (2020). A Simulation-Based Interactive Learning Multimedia Development for Photosynthesis and Respiration Practicum in Junior High Schools. Journal of Educational Technology \& Online Learning, 3(3), 311-339.

\begin{tabular}{l} 
Article Info \\
\hline Received : 07.06 .2020 \\
Revised : 29.06 .2020 \\
Accepted : 10.07 .2020 \\
\hline
\end{tabular}

Accepted : 10.07 .2020

\begin{abstract}
A practicum is beneficial in science learning to provide a concrete manifestation of a topic. This study aimed at creating a simulation-based interactive learning multimedia product to assist students' practicum. The product was developed for the topic of cell metabolism process focusing on the energy in living systems. The study employed the Research and Development referring to the Analysis, Design, Development, Implementation, and Evaluation model. During the development process, both product testing and users' response testing were carried out. To reveal the product impact, students' results of the pre-test and post-test were analyzed. The product was developed by using Macromedia Flash 8 . The results of Alpha and Beta analysis showed that the results are 'feasible' and 'very feasible' for the product. Furthermore, based on the average value of 39.2 for the initial test and 82.5 for the final test it was obtained an Ngain value of 0.712 with the category of "High". Therefore, it proved that the developed interactive learning multimedia is effective in increasing students' analytical skills for the Science Learning materials in junior high schools.
\end{abstract}

Keywords: ADDIE, Analytical skills, Cell metabolism, Interactive multimedia, Science learning.

\section{INTRODUCTION}

Instructional design focuses at a learner-centered approach for education, rather than a conventional teacher-centered approach, such that successful learning can take place. This means that each portion of the instruction is driven by the learning outcomes that have been determined through a detailed review of the needs of the learners (McGriff, 2000). İn this study, the instructional systems design called ADDIE model was applied. ADDIE is an instructional systems design (ISD) framework that many instructional designers and training developers use to develop course (Morrison,2010). The name is an acronym for the five phases it defines for building training and performance support tools: Analysis, Design, Development, 
Implementation, Evaluation. Most current ISD models are variations of the ADDIE process. Other models include the Dick and Carey and Kemp ISD models. Rapid prototyping is another common alternative. Instructional theories are important in instructional materials design. These include behaviorism, constructivism, social learning, and cognitivism (Piskurich, 2006). The benefit of the ADDIE model is that it is easy to use and can be implemented to a curriculum that focuses on teaching knowledge, skills or behaviors. However, regardless of the model used, a systematic, comprehensive approach to curriculum creation would allow educators to fulfill the needs of their learners.

Natural Sciences are subjects developed into the form of integrated sciences. The contents encompass the disciplines of biology, chemistry, and physics. The subject is one of the educational programs oriented towards application, the development of curiosity, thinking ability, learning ability, and caring attitude as well as responsibility towards the natural environment. Learning science emphasized on understanding the natural environment with all its wealth that needs to be preserved and maintained in the perspective of biology, chemistry, physics, and the whole. Therefore, learning science is expected to provide direct experience to develop the students' competencies to understand and analyze various natural events that occur in the surrounding environment.

The energy in living systems is one of the natural science materials studied in junior high schools. Besides discussing the concept of energy in physics, this material also explains the chemical processes that occur in the body cells of living things. One of the chemical processes in the body of living things is metabolism, which consists of formation/synthesis/anabolism reactions such as photosynthesis and decomposition/catabolism reactions such as respiration (Widodo, Rahmadiarti, Nurul, 2016). The chemical process cannot be seen directly with the naked eye so that students who are unable to think abstractly will have difficulty understanding it. After understanding the concept, students are expected to be able to analyze it.

Such as process, the analysis, is a manifestation of the primary objectives of learning science. An effort to facilitate the analysis process is by conducting the observation, experiment or practicum activities, where these activities require infrastructure such as laboratories (Altun, Baris, Burk, Alev \& Ilker 2009). However, the problem is that there are only 28,205 science laboratories in Indonesia, out of a total of 39,637 junior high schools spread throughout Indonesia (Ministry of Education and Culture, 2018). For instance, In Bulungan District, there 
are still more than $50 \%$ of junior high schools with no science laboratory, or if there is a laboratory at school, it has not been utilized properly.

The development of learning media is in line with the development of technology. As asserted by Siregar, et al. (2020), widely open sources of information and technology can be extensively utilized in giving a more comprehensive explanation and demonstration of the learning topics. Moreover, technology comes with an attractive offer where provides the innovation that enables teachers and students to develop better (Taopan, L. L., Drajati, N. A., \& Sumardi, 2020).

One of the growing learning media today is the simulation-based interactive multimedia, which presents experiences of its processes and observations. The experiences are believed to improve understanding and analytical skills in science learning, especially for abstract materials such as cell metabolism (on the subject of energy in the system life). Therefore, this study aimed to develop and produce simulation-based interactive multimedia for science practicum in junior high schools. Furthermore, this interactive multimedia product was tested to determine the feasibility and effectiveness of the Natural Sciences practicum in improving students' analytical skills at a junior high school in North Kalimantan of Indonesia.

\section{LITERATURE REVIEW}

The interpretations of Educational Technology have been evolving as long as the field has, and both of them evolve continuously (Januszewski \& Molenda, 2008). Seels \& Richey (1994) asserted that educational technology is the study and practice of ethics to facilitate learning and improve performance by creating, using, or utilizing and managing appropriate technological processes and resources. This view of educational technology was then reviewed by the Association of Educational Communication and Technology (AECT) resulting in a new definition shifiting into the latest beacon to guide our thinking of the 21 st century. AECT stated that Educational technology refers to the study and ethical application of facilitating education and improving performance by creating, using, and managing appropriate techological processes and resources (Januszewski \& Molenda, 2008).

As can be seen, the AECT's definition of educational technology encompasses some key terms. The first term, Study, implies that the understanding of educational technology requires perpetual knowledge construction and refinement through research and reflective practice. The second, Ethical practice, implies that the realization of educational technology should consider the ethical standards. Furthermore, ethics are not merely seen as rules or expectations. However, 
ethics should be acknowledged as a practical basis. The next is facilitating learning and improving performance. This key term reprepsents the purpose of the educational technology. In other words, the definition puts students' learning and performance at the forefront of our field of study and practice.

Also, the definition mentioned three functions integrated to the concept of educational technology; creating, using, and managing. These functions can be seen as a larger process of instructional development. They should be accompanied by evaluation processes at each phase as monitoring actions and making corrective actions at each phase are critical.

The last key term is technological processes and resources. It tells us what we work with. The term technological refers to an approach to human activity based on systematic applications of scientific or other organized knowledge to practical tasks (Januszewski \& Molenda, 2008). Further, the term processes indicates that there are series of activities directed to achieve a particular result. Meanwhile, the term resources is extended to technological variations and the development of new understandings concerning how the technological tools might help learners (Januszewski \& Molenda, 2008).

Regarding the educational process, learning taking place in schools today has experienced rapid development in which technology becomes vital. Moreover, the role of technology in learning is usually related to the development of instructional media. Rusman, Kurniawan \& Riyana (2011) classified the types of learning into five types: visual media, audio media, audio-visual media, presenter media groups, and object media and computer-based interactive media.

If associated with the term learning multimedia, it can be explained that learning multimedia is a combination of all types of media, including visuals in the form of both still and moving images that illustrate learning material. It includes audio and audio-visual media to support learning. Besides, learning multimedia presents learning materials following pertinent to objectives to be achieved. Generally, multimedia learning is also an interactive media demanded to present two-way communication with users. Multimedia learning can be computer-based or Android. Furthermore, a multimedia is considered as a tool that can create dynamic and interactive presentations that combine text, graphics, animation, audio and video. An interactive multimedia is one of the computer-based learning media. The characteristic of interactive multimedia is the existence of a controller, commonly called the Graphical User Interface (GUI). It is usually in the form of icons, buttons, scrolls, or others. Information 
presented through this multimedia contains an animated document. It can be viewed on a monitor screen or projected onto the big screen via an overhead projector. Further, it can be heard, and its movement (video or animation) can be seen. Interactive multimedia helps to present some sorts of information that is fun, interesting, easy to understand, and clear. Such information will be understandable since our senses, especially the ears and eyes can be used to absorb the information. Furthermore, Warsita (2008) explained that multimedia interactive learning has a number of advantages over other media, including being flexible, self-pacing (serving the speed of individual learning), content-rich (rich content), interactive, and individual.

For the study, interactive multimedia was designed as a simulation-based multimedia for natural science learning. Rusman, Kurniawan \& Riyana (2011) asserted that the simulation model in CBI (Computer-Based Instruction) is can provide a more concrete learning experience by creating imitations of experiences that match the actual arrangement. Arsyad (2011) also elaborated that a computer-assisted simulation program tries to match the dynamic processes in the real world. Furthermore, Darmawan (2012) divided the simulation model into four categories of models, namely (1) physical, (2) situation, (3) product, and (4) process, where each category follows certain interests. In short, simulation is considered beneficial as students in practical activities need to be given clear instructions to help students conduct experiments (Arifah et al., 2014).

There have been many development studies producing interactive multimedia science products. Research by Hotimah and Ali Muhtadi (2017) produced interactive learning multimedia products that are proven to increase students' understanding of microorganism material. In their study, the post-test results revealed that $83 \%$ of the students achieved higher learning outcomes than the standard score (75) with an average achievement of 80.5. The statistical analysis of the paired sample t-test noted that the increase in student understanding after using the interactive science learning multimedia product is significant $(0,000)$. Thus, it was concluded that this interactive learning multimedia is proven to increase student understanding of microorganism material. Furthermore, Larasati's research (2014), obtained the results that the use of IT-based simulation media in physics learning can improve understanding concepts and learning activeness in students across physics interests in a State High School in Pekalongan. The magnitude of the increase in student understanding was $30 \%$, while an increase in learning activeness reached $33.5 \%$. 
Based on the aforementioned background, this study is conceptually different from the previously existing researches in which the interactive multimedia was focused on the material of cell metabolism on the subject of energy in living systems. As known, such a material has an abstract concept. Therefore, it is expected to be more understandable through practical activities. Nonetheless, as limited above, the availability of laboratories is the biggest challenge in practicing. Accordingly, this product can be an appropriate solution to this issue.

\section{METHODOLOGY}

This study employed a research and development design, referring to the ADDIE development model. Dick and Carry (1996) introduced the ADDIE model for the design of a learning system. Allen (2006) described the design stages of ADDIE development model as follows:

\begin{tabular}{|c|l|}
\hline Analysis & $\begin{array}{l}\text { Analyzing the needs to determine the problem and the appropriate solution and } \\
\text { to determine the competence of students. }\end{array}$ \\
\hline Implementation & $\begin{array}{l}\text { Determining the learning approach, developing a framework, mapping the needs } \\
\text { of the simulation-based Interactive Learning Multimedia. }\end{array}$ \\
\hline Evaluation & $\begin{array}{l}\text { Developing simulation-based Interactive Learning Multimedia under the chosen } \\
\text { learning approach. }\end{array}$ \\
\hline Conducting analyses and repairing errors that occur during learning.
\end{tabular}

Figure 1. ADDIE Development Model

The formative evaluation conducted in this study consisted of the alpha test and the beta test. The alpha test is a validity test by both media experts and natural science experts at the end of the development phase. The test results of the alpha test were used to make initial improvements toward the prototypes that were developed before being tested on users or students. Afterwards, the following is the beta test, a product assessment by the users. This stage involved six respondents, extended to 1 science teacher and 5 grade VII students at a state junior high school in North Kalimantan of Indonesia. 
A questionnaire was administered to obtain data about the response of media experts, material experts, and students towards the interactive multimedia. As asserted by Sugiyono (2011), the questionnaire is a data collection technique done by giving a set of questions or written statements to the respondent to answer. The questionnaire used in this study was a direct questionnaire with an answer scale (rating scale). The questionnaire is divided into the media expert feasibility test instrument and the material expert feasibility test instrument. Also, the analysis ability test was conducted to test the effectiveness of simulation-based interactive learning multimedia.

Data analysis techniques were carried out to obtain a feasible Interactive Learning Multimedia) that is quality, valid, practical, and effective based on data groups that have been adapted to the type of data. Following is the description of each instrument. The ILM assessment score is used to obtain validity of the developed ILM data, while the Response Questionnaire is used to obtain practicality data on the use of the ILM. Validity data was obtained from assessments by material expert lecturers, media expert lecturers, and mathematics teachers who collaborated with researchers in learning. The steps developed in analyzing data from the ILM assessment sheet and response questionnaire are:

Transforming qualitative data into quantitative data with the Likert scale provisions in the table below.

Table 1

ILM assessment data scoring rules

\begin{tabular}{ll}
\hline Classification & Score \\
\hline Very good & 5 \\
Good & 4 \\
Moderate & 3 \\
Bad & 2 \\
Very bad & 1 \\
\hline
\end{tabular}

Converting the average score into a qualitative value by the assessment aspects in table 2 below. 
Table 2

ILM final assessment classification guidelines for response questionnaire

\begin{tabular}{ll}
\hline Score Range & Classification \\
\hline $\bar{x}>4,2$ & Very feasible \\
$3,4<\bar{x}>4,2$ & Feasible \\
$2,6<\bar{x}>3,4$ & Enough \\
$1,8<\bar{x}>2,6$ & Low \\
$\bar{x}<1,8$ & Very low \\
\hline
\end{tabular}

\section{Data Analysis of Product Effectiveness Test}

The effectiveness test of the interactive learning multimedia was carried out by using One Group Pretest-Posttest Design (Isaac \& Michael, 1995), which is a trial design using one group or class to get data on the cognitive learning outcomes of students through the initial test (pretest) and the final test (post-test). The comparison of student learning outcomes obtained before and after using this interactive learning multimedia was calculated with the Normalized-gain formula by (Sundayana, 2014). The formula is as follows:

$$
g=\frac{S \text { post }-S \text { pre }}{S \text { maks }-S \text { pre }}
$$

Where

$$
\begin{aligned}
& S \text { post }=\text { Average score of post-test } \\
& S \text { pre }=\text { Average score of pre-test } \\
& S \text { max }=\text { Maximum score }
\end{aligned}
$$

Results obtained from these calculations were then converted according to the following gain value categories:

Table 3

Gain Value Conversion

\begin{tabular}{lll}
\hline No & Gain Value & Categories \\
\hline 1 & $\mathrm{~g} \geq 0,70$ & High \\
2 & $0,70>\mathrm{g} \geq 0,3$ & Medium \\
3 & $\mathrm{~g}<0,30$ & Low \\
\hline
\end{tabular}




\section{FINDINGS AND DISCUSSIONS}

This section elaborates on the encountered findings which are extended on the adjustment which is relevant to the study focus. The product produced in this study is a simulation-based interactive learning multimedia for Natural Sciences at grade VII of junior high schools pertinent to the proposed problem limitations.

\section{Analysis}

Researchers conducted several analyses in this stage, including analysis of needs, analysis of curriculum, and student characteristics analysis. Based on the results of observations and interviews with science teachers of grade VII, it was obtained that the obstacles that were often encountered in the science practicum were the availability of practical tools and materials, as well as the replacement media. The unavailability of practicum tools and materials causes no practicum activities. In contrast, the absence of practicum replacement media causes the instructor to only use modest media during the educational process, such as books. This finding is in line with a study by Siregar, et al. (2019) that school facilities could be an external challenging factor regarding the success of educational process.

Moreover, the science teacher elaborated that books cannot facilitate science practicum activities. Even though schools have electronic media in the form of computers, they have not yet been utilized optimally. Accordingly, the learning process is still monotonous and causes a lack of experience of students related to science practicum. Further, it results in low student analytical skills.

For curriculum analysis, it was encountered that science subject has a broad scope covering physics, chemistry and biology. The material chosen is energy in living systems, specifically the concepts of photosynthesis and respiration. The selection of these materials was carried out by regarding the consultation results with the science teachers. These materials were chosen because of the frequent misunderstanding of concepts due to the absence of practicum and the limitations of learning media. In general, the concept of the materials is quite simple, yet it becomes abstract without maximum visualization. With this regard, learning media is undoubtedly necessary to assist the practicum activities so that students can easily understand the topics.

Furthermore, for the analysis of students' characteristics, grade VII of junior high schools are teenagers. They are in the stage of formal operational development (11-15 years), where 
children have begun to have the ability to think abstractly, reason logically, and draw conclusions (analysis) from the information obtained. Despite having the ability to think abstractly, if the information obtained does not match the actual concept, the students will draw wrong conclusions.

\section{Design}

The designing process encompassed several stages. The first was to determine the standard competencies. The second was to create flowcharts after knowing the design of multimedia content. The third was to create storyboards to provide descriptions in each frame by listing all the used multimedia objects.

\section{Development}

The development phase was carried out after the design process (design). In this stage, several steps were carried out. Firstly, the collection of materials needed in the form of learning materials and pictures that support the material and audio was conducted. Afterward, the creation of interactive learning multimedia was started. The multimedia was developed by utilizing Macromedia Flash 8 software. The results of the media are displayed below.

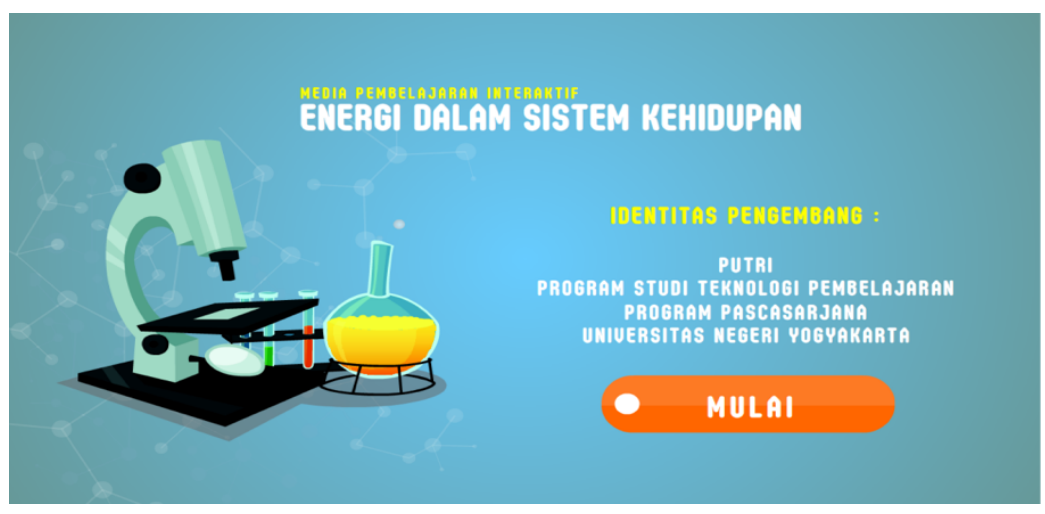

Figure 2. Title page

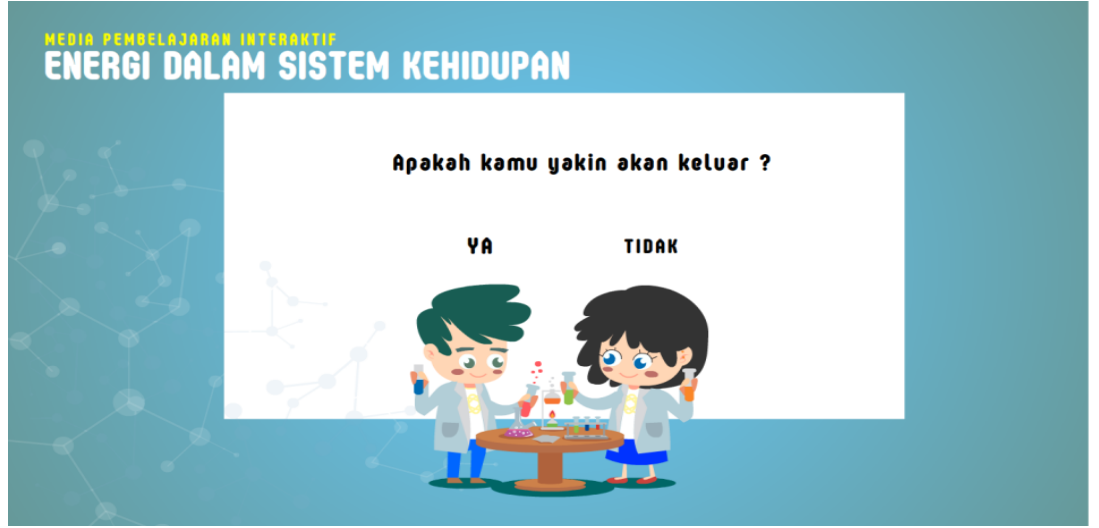

Figure 3. Exit page 


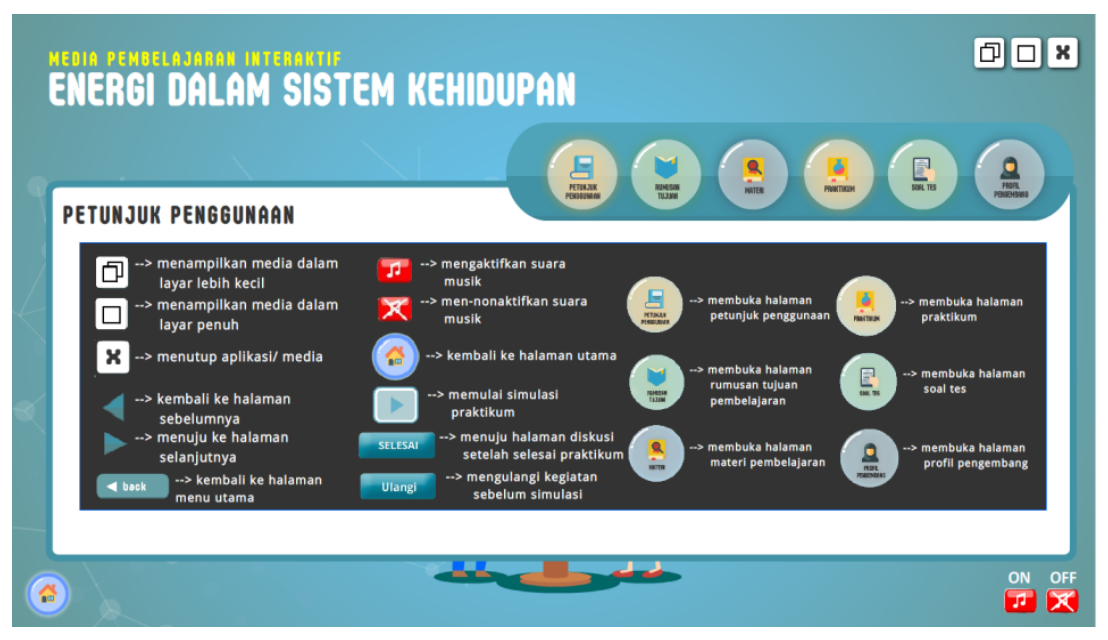

Figure 4. Instruction page

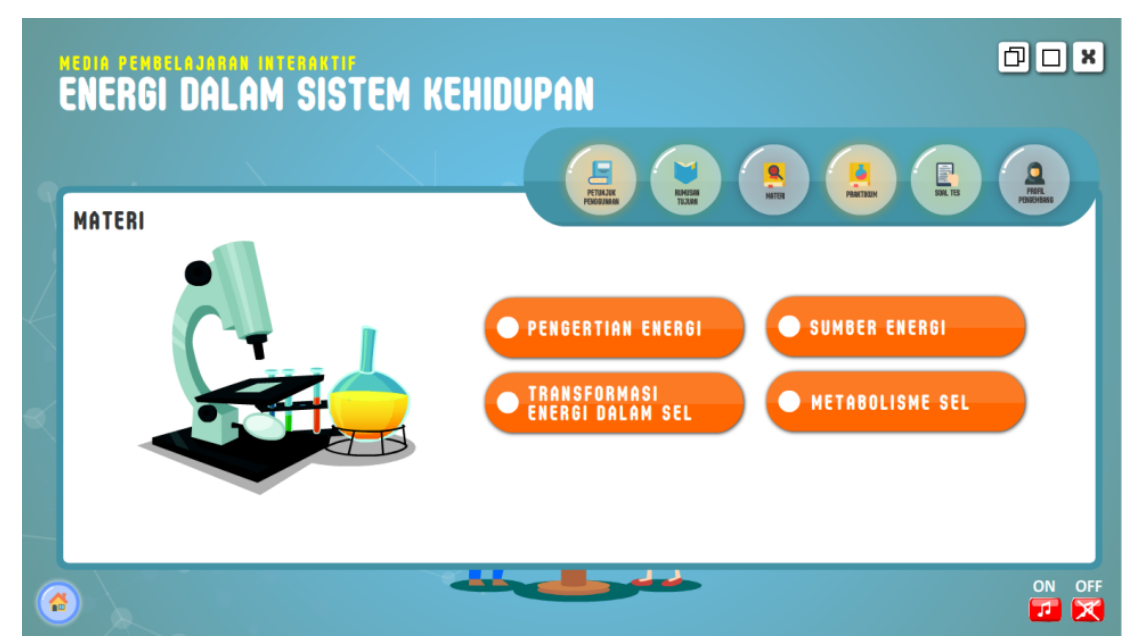

Figure 5. Learning materials

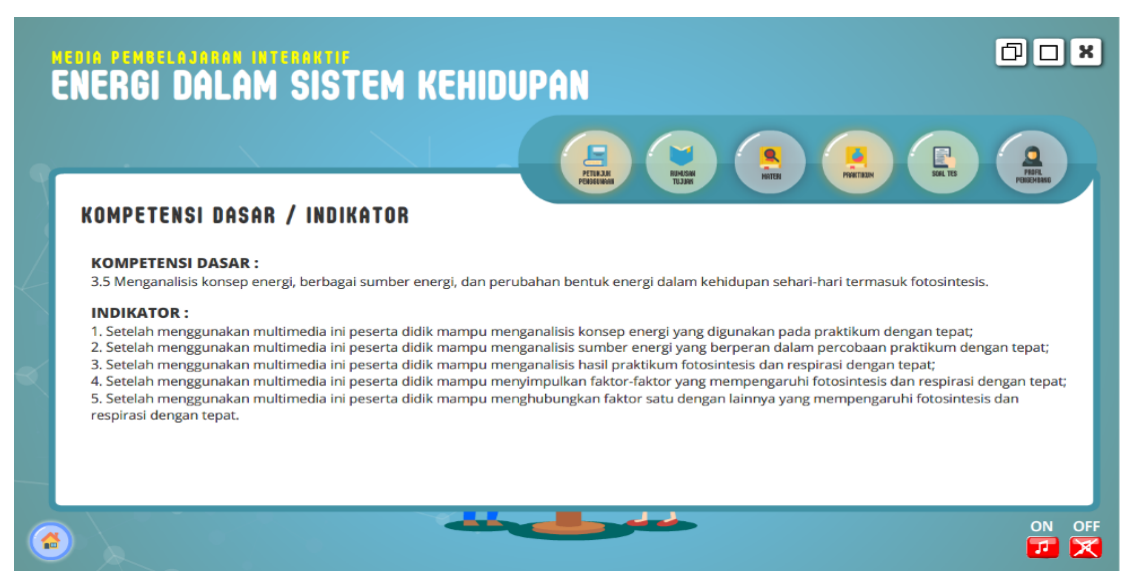

Figure 6. Formulation page 


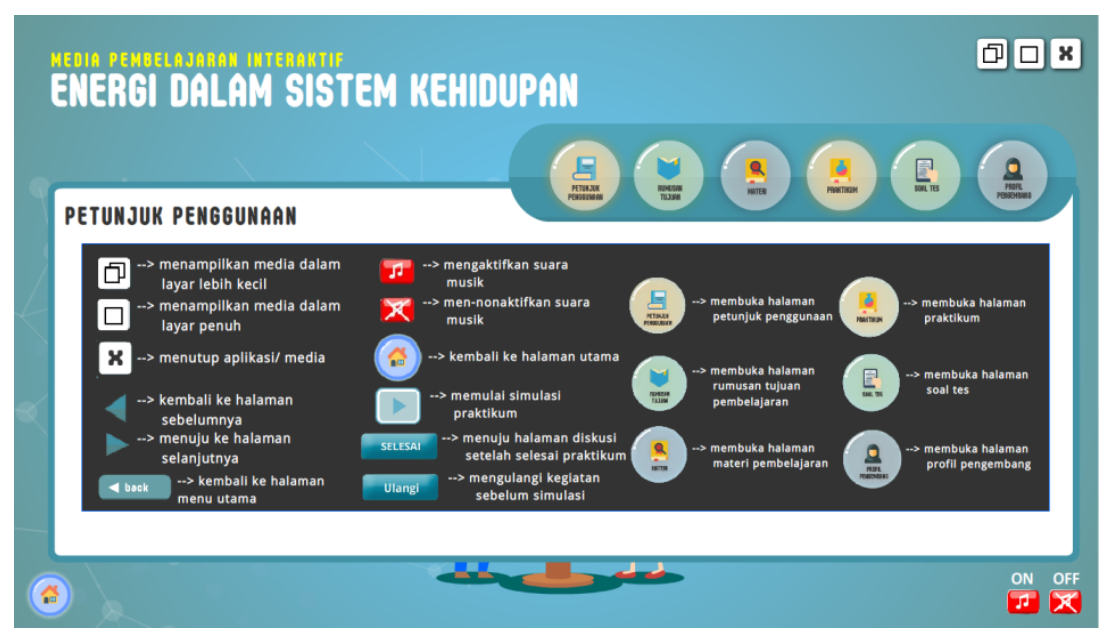

Figure 7. Learning materials

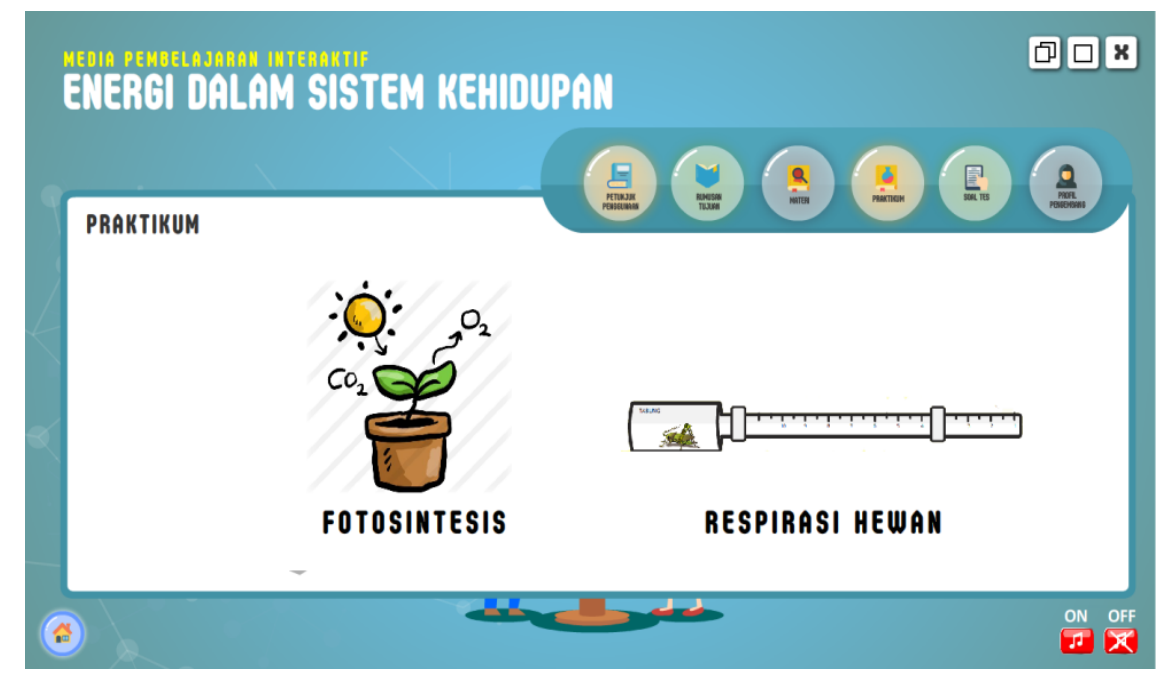

Figure 8. Practice page

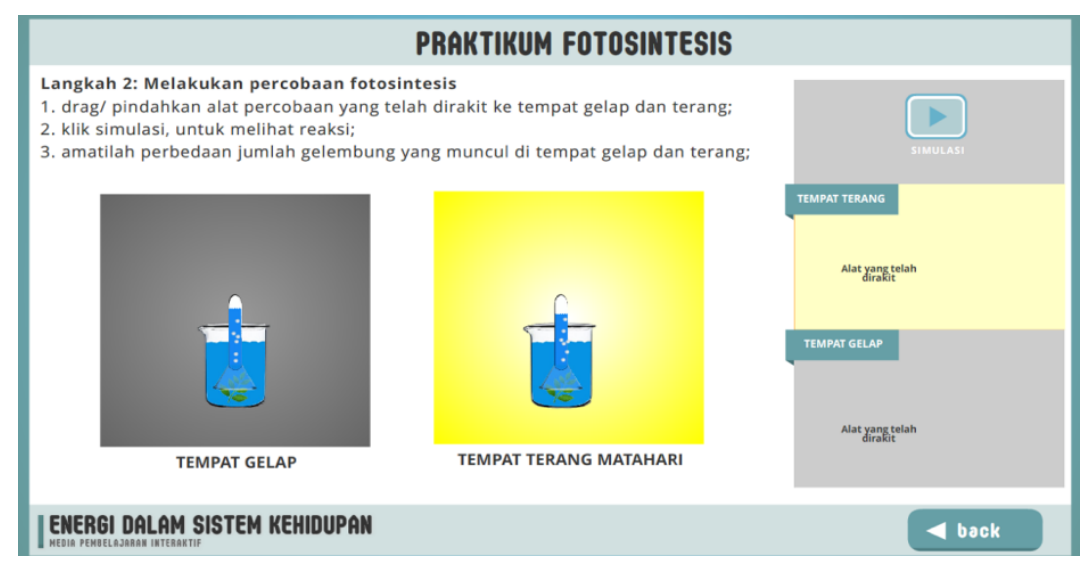

Figure 9. Photosynthesis practicum page (tools and materials) 


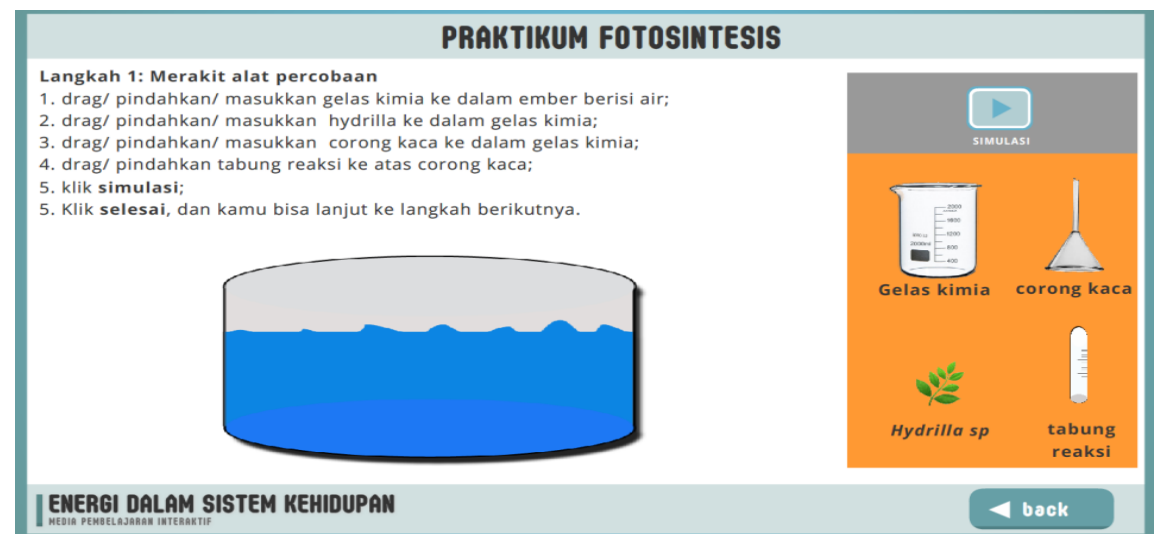

Figure 10. Photosynthesis practicum page (assembling experimental equipment)

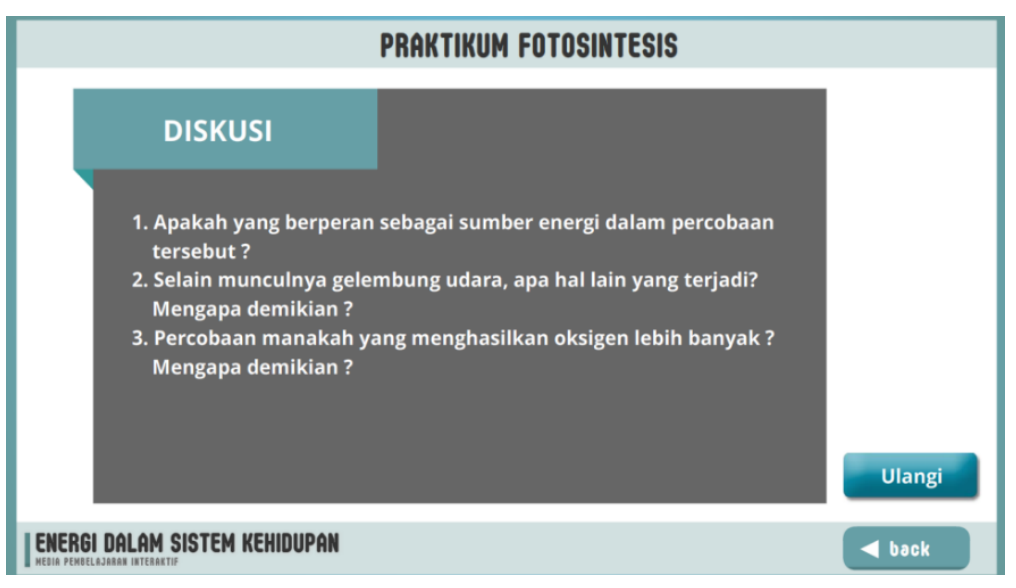

Figure 11. Practicum page (conducting photosynthesis experiment)

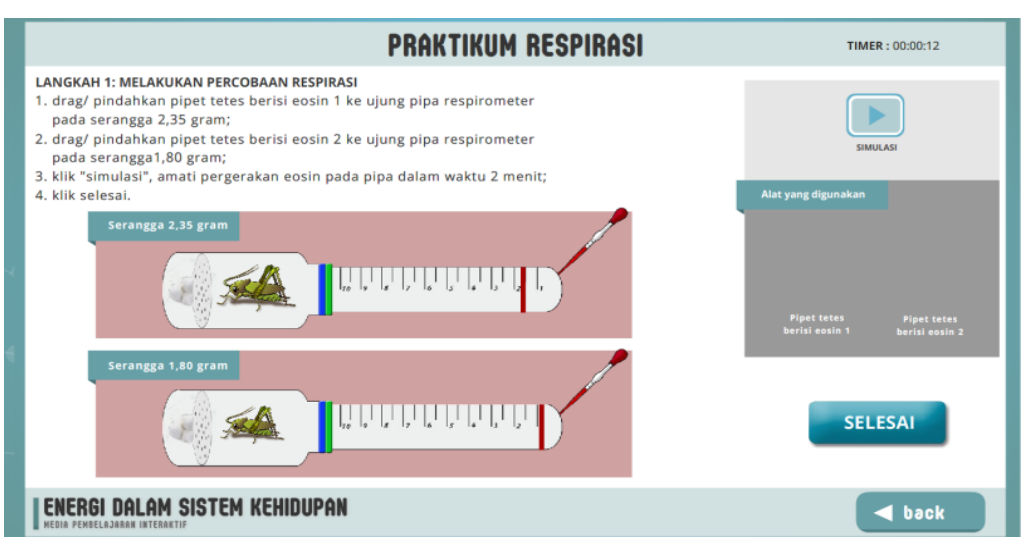

Figure 12. Photosynthesis practicum page (discussion) 


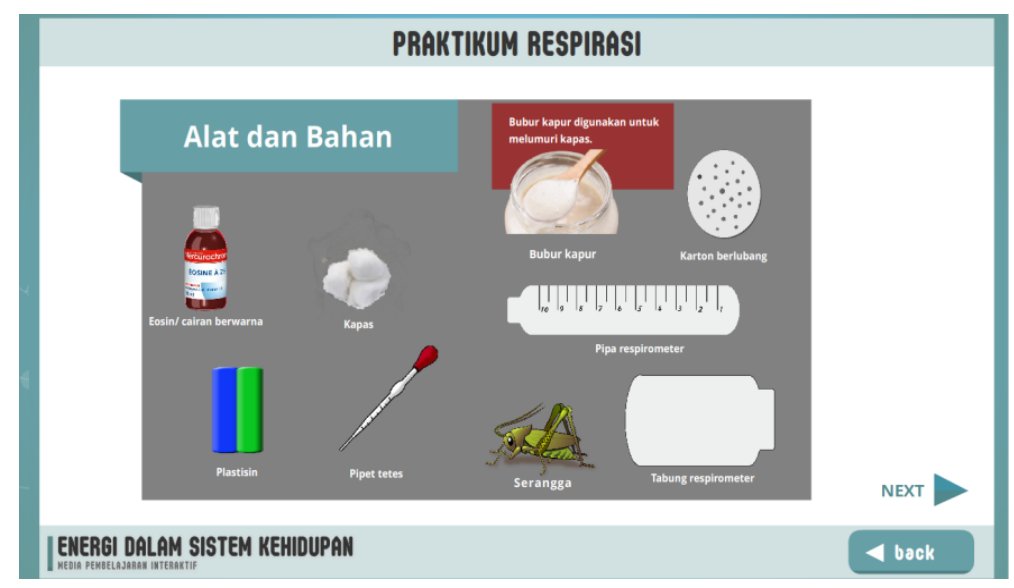

Figure 13. Respiration practicum page (tools \& materials)

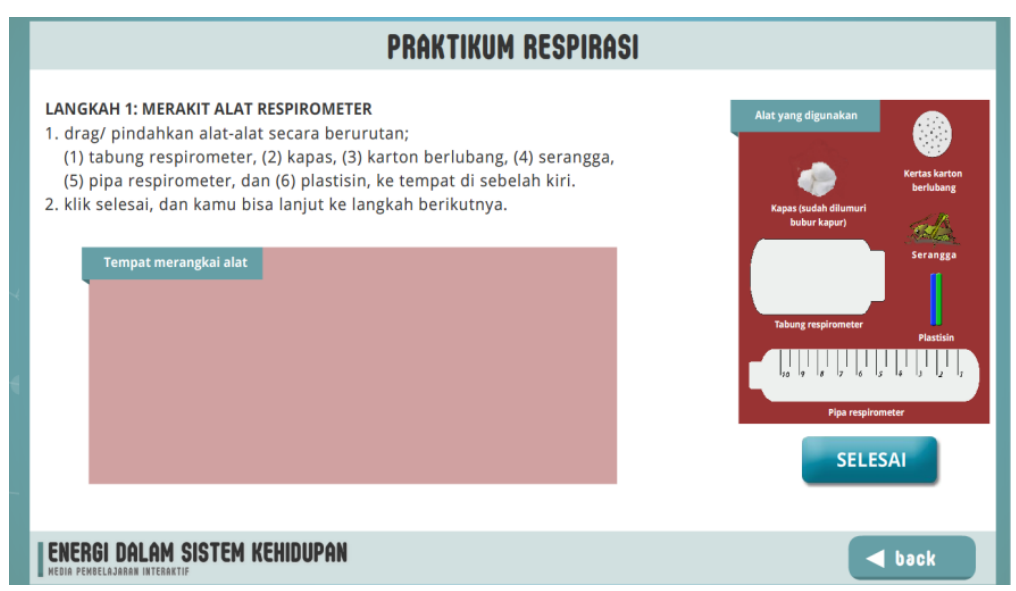

Figure 14. Respiration practicum page (assembling a respirometer)

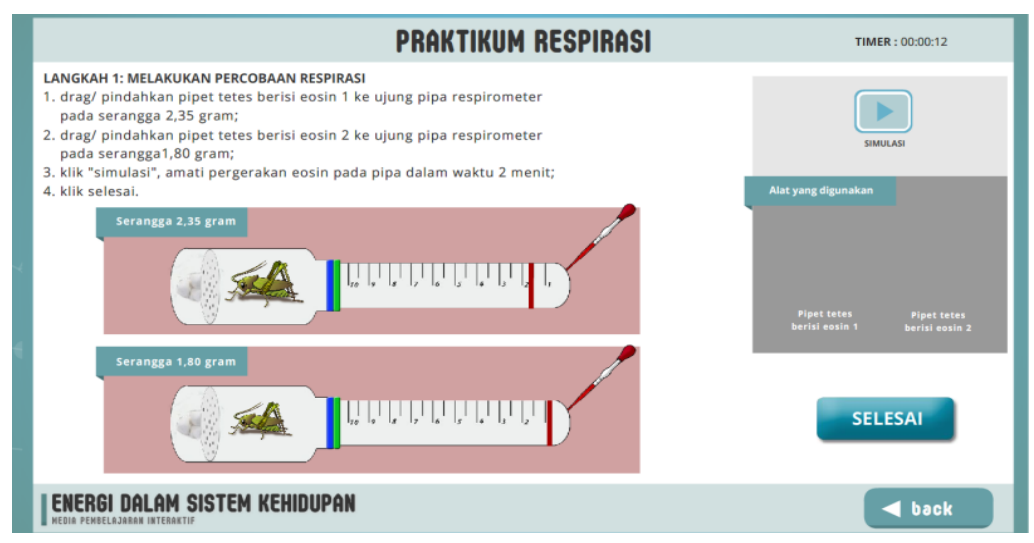

Figure 15. Respiration practicum page (conducting respiration experiment) 


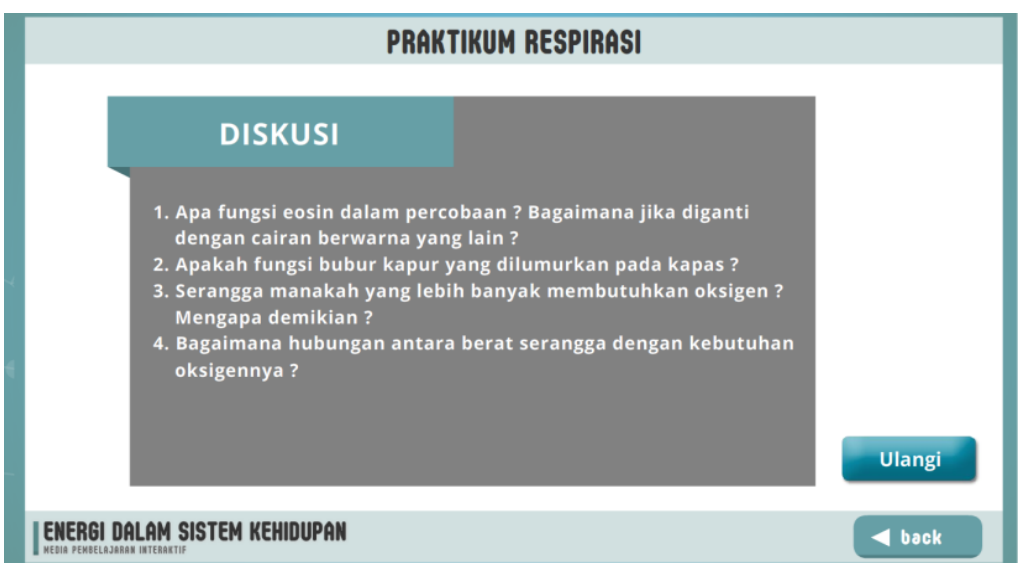

Figure 16. Respiration practicum page (discussion)

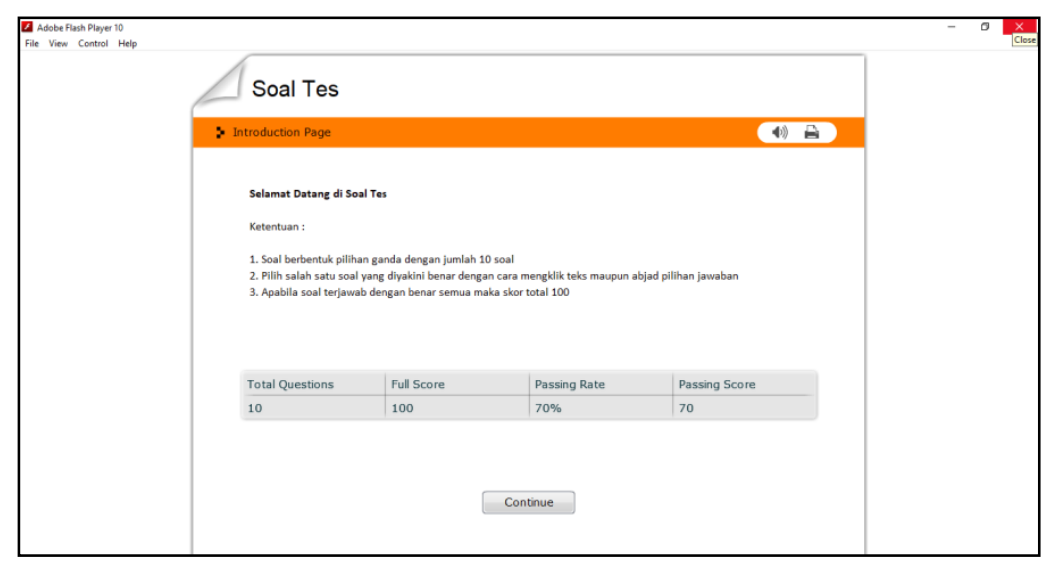

Figure 17. Quiz page

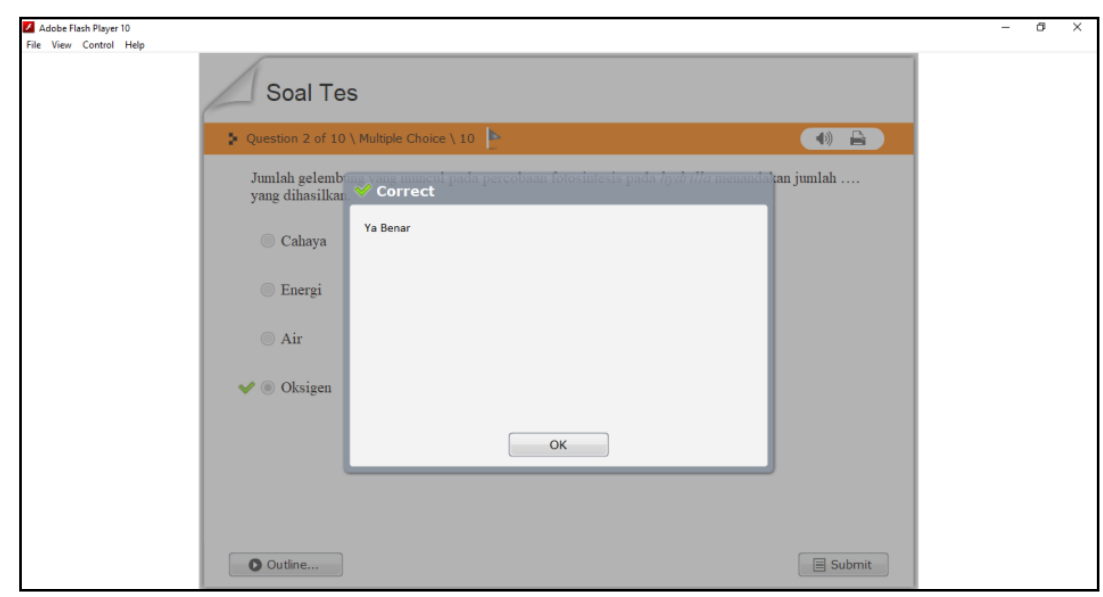

Figure 18. Quiz page (feedback/ correct answers) 


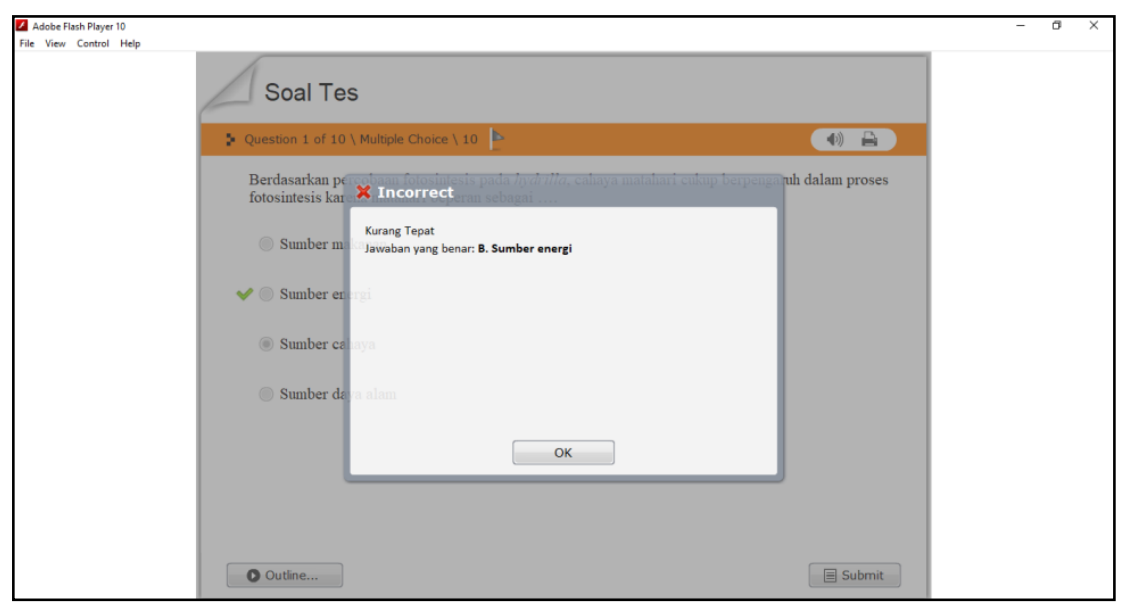

Figure 19. Quiz page (feedback/ incorrect answers)

After the interactive multimedia product had been made, the next step was the Alpha test in instrument assessment, media validation, and material validation. Such validation was carried out by experts who are considered competent in this field so that the testing is carried out with measurable professional standards. The Alpha validation results are shown in the following table:

Table 4

Results of media expert assessment

\begin{tabular}{llll}
\hline No & Indicators & Score & Criteria \\
\hline Software Engineering Aspects & & \\
1 & $\begin{array}{l}\text { Simulation methods are developed according to the purpose of } \\
\text { development }\end{array}$ & $\mathbf{4}$ & Feasible \\
2 & Maintainable \& manageable & $\mathbf{5}$ & Very feasible \\
3 & Usability (easy to use and simple to operate) & $\mathbf{4}$ & Feasible \\
4 & Selection of application type/software in proper media development & $\mathbf{5}$ & Very feasible \\
5 & Compatibility (media can be installed and run on various hardware & $\mathbf{4}$ & Feasible \\
& and software) & 4 & Feasible \\
6 & Easy program installation & $\mathbf{4}$ & Feasible \\
7 & Instructions are clear and systematic & $\mathbf{4}$ & Feasible \\
\hline
\end{tabular}




\begin{tabular}{|c|c|c|c|}
\hline 9 & Videos in media programs are easy to set (control) & 4 & Feasible \\
\hline 10 & Simulation program in the media is easy to set (control) & 5 & Very feasible \\
\hline 11 & Navigations are easy to run & 5 & Very Feasible \\
\hline 12 & Media and users have high interactivity & 4 & Feasible \\
\hline \multicolumn{4}{|c|}{ Display } \\
\hline 13 & Good choice of font and arrangement & 4 & Feasible \\
\hline 14 & $\begin{array}{l}\text { The layout of the images is harmonious and attractive, so it serves as } \\
\text { a good material illustration (Layout design) }\end{array}$ & 5 & Very feasible \\
\hline 15 & $\begin{array}{l}\text { The choice of colors supports the suitability between the concept and } \\
\text { the chosen topic }\end{array}$ & 4 & Feasible \\
\hline 16 & $\begin{array}{l}\text { The quality and selection of images that are appropriate and in } \\
\text { accordance with the concepts and topics are chosen }\end{array}$ & 4 & Feasible \\
\hline 17 & $\begin{array}{l}\text { The quality and selection of images are appropriate and in } \\
\text { accordance with the concepts and topics are chosen }\end{array}$ & 5 & Very feasible \\
\hline 18 & $\begin{array}{l}\text { The quality and selection of images are appropriate and in } \\
\text { accordance with the concepts and topics are chosen }\end{array}$ & 4 & Feasible \\
\hline 19 & $\begin{array}{l}\text { Quality and selection of videos are appropriate and in accordance } \\
\text { with the concepts and topics are chosen }\end{array}$ & 4 & Feasible \\
\hline 20 & $\begin{array}{l}\text { Back sound selection is appropriate that it does not distract users' } \\
\text { concentration. }\end{array}$ & 4 & Feasible \\
\hline 21 & $\begin{array}{l}\text { The narration is displayed in the good and correct language, so it is } \\
\text { understandable. }\end{array}$ & 4 & Feasible \\
\hline \multicolumn{2}{|c|}{ Average } & 4,2 & Feasible \\
\hline
\end{tabular}

Table 5

\section{Material validation data}

\begin{tabular}{llll}
\hline No & Indicators & Score & Criteria \\
\hline Standard Aspect of Content & & \\
1 & $\begin{array}{l}\text { Clarity of learning objectives (reliability and } \\
\text { measurability) }\end{array}$ & Very feasible \\
2 & $\begin{array}{l}\text { The relevance of learning objectives to } \\
\text { standard competencies (curriculum) }\end{array}$ & Very Feasible \\
\hline
\end{tabular}




\begin{tabular}{|c|c|c|c|}
\hline 3 & The concept is theoretically appropriate & 4 & Feasible \\
\hline 4 & $\begin{array}{l}\text { The illustration is theoretically and } \\
\text { conceptually appropriate }\end{array}$ & 4 & Feasible \\
\hline 5 & $\begin{array}{l}\text { The suitability of the animation with the } \\
\text { material }\end{array}$ & 5 & Very feasible \\
\hline 6 & Adequacy of material & 4 & Feasible \\
\hline 7 & $\begin{array}{l}\text { The similarity of simulations with the real } \\
\text { processes }\end{array}$ & 4 & Feasible \\
\hline 8 & Material depth & 4 & Feasible \\
\hline \multicolumn{4}{|c|}{ Learning aspects } \\
\hline 9 & The tangles of the material presented & 4 & Feasible \\
\hline 10 & $\begin{array}{l}\text { The suitability of the material with the } \\
\text { learning objectives }\end{array}$ & 5 & Very feasible \\
\hline 11 & Understandability & 4 & Feasible \\
\hline 12 & Clarity of material description & 4 & Feasible \\
\hline 13 & $\begin{array}{l}\text { The suitability of the evaluation tools with the } \\
\text { learning objectives }\end{array}$ & 4 & Feasible \\
\hline 14 & $\begin{array}{l}\text { The ability of evaluation instruments to } \\
\text { measure the achievement of objectives }\end{array}$ & 4 & Feasible \\
\hline 15 & $\begin{array}{l}\text { The ability of feedback to motivate student } \\
\text { learning }\end{array}$ & 5 & Very feasible \\
\hline \multicolumn{2}{|c|}{ Average } & 4,34 & Very feasible \\
\hline
\end{tabular}

Based on the table, it can be explained that the material expert assessed the material of the interactive learning multimedia with an average value of 4.34 with the criteria "Very Feasible". The experts' assessment revealed that this interactive learning multimedia was ready to use in the next stage with some suggestions and improvements. 


\section{Implementation}

The next stage, after getting the product's feasibility from the experts, is the implementation phase. At this stage, researchers conducted trials of products that had been developed and validated. There were two stages conducted by researchers, namely product trials and testing of users' responses from both students and subject matter teachers.

At the product trial stage, students were asked to try all the menus in multimedia. In addition, researchers also guided them in carrying out practical simulation activities. Both students and teachers were also asked to try these multimedia products. It was done to obtain more leverage data. After trying all the menus and doing a practical simulation, the researcher asked the students to work on the post-test problem presented in the multimedia product.

After researchers had tested the product and tested the effectiveness, the next step was the Beta testing phase. This was the last stage in the implementation phase. This test was conducted by involving six respondents, extended to 5 students and 1 science teacher. The results are then used as improvements to the product being developed. Students and teachers provided their responses in a questionnaire that had been validated by an assessment instrument expert. Beta test results can be seen in the following table:

Table 6

Data of Teachers' Response

\begin{tabular}{|c|c|c|c|}
\hline No & Indicators & Score & Criteria \\
\hline 1 & $\begin{array}{l}\text { Interactive learning multimedia make science learning more } \\
\text { interesting }\end{array}$ & 4 & Feasible \\
\hline 2 & $\begin{array}{l}\text { Interactive learning multimedia makes learning science } \\
\text { easier }\end{array}$ & 4 & Feasible \\
\hline 3 & $\begin{array}{l}\text { Interactive science learning multimedia can increase student } \\
\text { motivation }\end{array}$ & 5 & Very feasible \\
\hline 4 & $\begin{array}{l}\text { Simulation-based interactive learning multimedia for } \\
\text { science practicums can improve students' analytical skills. }\end{array}$ & 4 & Feasible \\
\hline 5 & Interactive learning multimedia is easy to use. & 5 & Very feasible \\
\hline 6 & $\begin{array}{l}\text { Interactive learning multimedia display is interesting, so } \\
\text { learning science is fun. }\end{array}$ & 4 & Feasible \\
\hline 7 & The instructions are clear and easy to understand. & 4 & Feasible \\
\hline 8 & The material presented is understandable. & 5 & Very feasible \\
\hline
\end{tabular}




\begin{tabular}{llll}
\hline 9 & $\begin{array}{l}\text { The material presented is in accordance with the learning } \\
\text { objectives }\end{array}$ & $\mathbf{5}$ & Very feasible \\
$10 \quad$ Completeness of material to achieve learning objectives & $\mathbf{4}$ & Feasible \\
$11 \quad$ Displayed images make the material easier to understand & $\mathbf{5}$ & Very feasible \\
$12 \quad \begin{array}{l}\text { Music/back sound on the media makes learning more } \\
\text { interesting. }\end{array}$ & Very feasible \\
$13 \quad \begin{array}{l}\text { The evaluation instrument can measure the achievement of } \\
\text { objectives. }\end{array}$ & Feasible \\
$14 \quad \begin{array}{l}\text { Practical simulations on the media make learning science } \\
\text { more interesting and enjoyable }\end{array}$ & $\mathbf{5}$ & Very feasible \\
$15 \quad \begin{array}{l}\text { Practical simulations on the media facilitate the learning } \\
\text { activities of science }\end{array}$ & $\mathbf{5}$ & Very feasible \\
Average & $\mathbf{4 , 5 3}$ & Very feasible \\
\hline
\end{tabular}

\section{Table 7}

\section{Data of Students' Response}

\begin{tabular}{|c|c|c|c|c|c|c|c|c|}
\hline \multirow[t]{2}{*}{ No } & \multirow[t]{2}{*}{ Indicators } & \multicolumn{5}{|c|}{ Score } & \multirow{2}{*}{$\begin{array}{l}\text { Averag } \\
\text { e }\end{array}$} & \multirow[t]{2}{*}{ Categories } \\
\hline & & P1 & $\mathbf{P 2}$ & $\mathbf{P 3}$ & P4 & P5 & & \\
\hline \multirow[t]{2}{*}{1} & $\begin{array}{l}\text { Interactive learning multimedia } \\
\text { make science learning more }\end{array}$ & & & & & & & Very good \\
\hline & interesting & 5 & 5 & 5 & 4 & 4 & 4.6 & \\
\hline \multirow[t]{2}{*}{2} & Interactive learning multimedia & & & & & & & Very good \\
\hline & makes learning science easier & 5 & 5 & 5 & 5 & 5 & 5 & \\
\hline \multirow[t]{2}{*}{3} & Interactive learning multimedia is & & & & & & & Very good \\
\hline & easy to use & 4 & 5 & 5 & 5 & 5 & 4.8 & \\
\hline \multirow[t]{2}{*}{4} & Interactive learning multimedia & & & & & & & Very good \\
\hline & $\begin{array}{l}\text { aspray is mineresting, so learning } \\
\text { science is fun. }\end{array}$ & 4 & 5 & 5 & 4 & 4 & 4.4 & \\
\hline \multirow[t]{2}{*}{5} & The instructions are clear and easy & & & & & & & Very good \\
\hline & to understand. & 5 & 5 & 5 & 5 & 5 & 5 & \\
\hline \multirow[t]{2}{*}{6} & The material & & & & & & & Very good \\
\hline & understandable. & 5 & 4 & 5 & 5 & 5 & 4.8 & \\
\hline \multirow[t]{2}{*}{7} & Display images make the material & & & & & & & Very good \\
\hline & easier to understand & 4 & 5 & 5 & 5 & 5 & 4.8 & \\
\hline \multirow[t]{2}{*}{8} & Music / back sound on the media & & & & & & & Very good \\
\hline & makes learning more interesting. & 4 & 4 & 4 & 5 & 5 & 4.4 & \\
\hline
\end{tabular}




\begin{tabular}{|c|c|c|c|c|c|c|c|c|}
\hline 9 & $\begin{array}{l}\text { Questions are clearly presented } \\
\text { and understandable }\end{array}$ & 4 & 4 & 5 & 5 & 5 & 4.6 & Very good \\
\hline 10 & $\begin{array}{l}\text { Practical simulations on the media } \\
\text { make learning science more } \\
\text { interesting and enjoyable }\end{array}$ & 5 & 5 & 5 & 5 & 5 & 5 & Very good \\
\hline \multicolumn{2}{|l|}{ Total } & 45 & 47 & 49 & 48 & 48 & 47.4 & Very good \\
\hline \multicolumn{9}{|c|}{ Average } \\
\hline & & 4.5 & 4.7 & 4.9 & 4.8 & 4.8 & 4.74 & \\
\hline
\end{tabular}

The table showed the science teacher's response in evaluating this interactive learning multimedia with an average value of 4.53 on a scale of 5 with the criteria "Very Feasible." Meanwhile, the five students gave an average value of 4.74 to this multimedia with the same criteria: "Very Good." The following is the assessment of multimedia interactive learning by the user as a whole presented in a bar diagram.

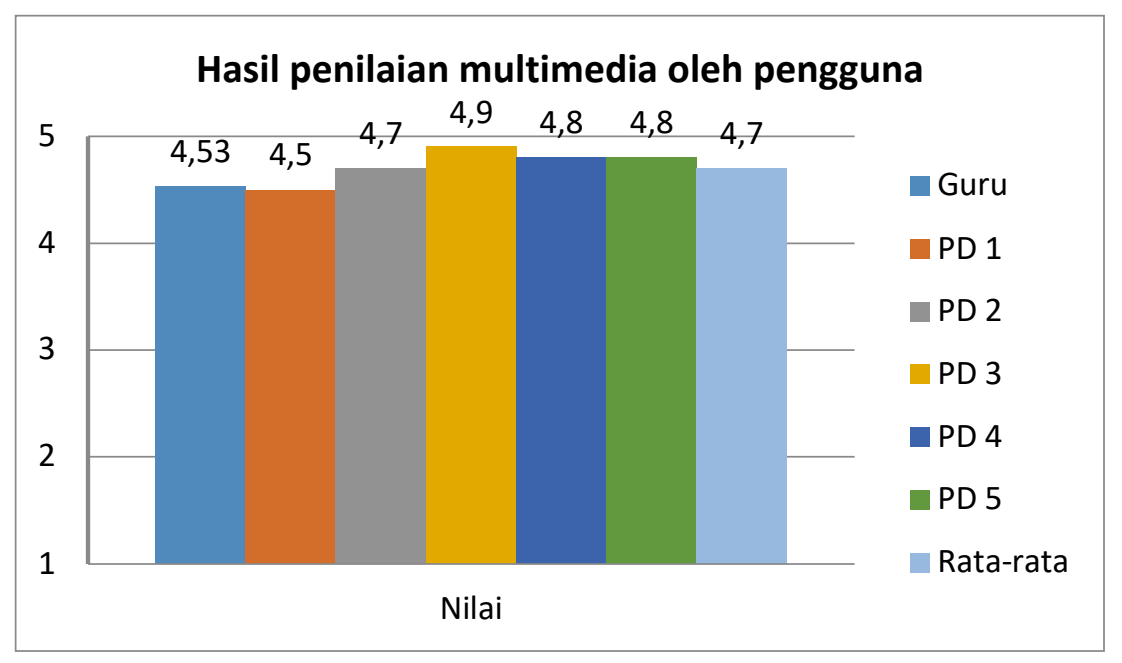

Figure 20. Results of Users' Assessment

Quantitatively, these results indicated that interactive learning multimedia is in the category of "Very Feasible / Good" with an average rating of 4.7 based on the response from the users. Additionally, there are no suggestions or improvements from users on this multimedia.

\section{Evaluation}

Evaluation is the final stage of the ADDIE development model. The evaluation was conducted by analyzing the obtained data. Moreover, the researchers also analyzed the pre-test and posttest results, which were used to determine differences in students' abilities before and after using 
the interactive learning multimedia. The initial test results (pre-test) and final tests (post-test) obtained are presented in the following table 5.

Table 8

The Results of Pre-test and Post-test

\begin{tabular}{|c|c|c|}
\hline No & Pre-test score & Post-test score \\
\hline 1 & 50 & 90 \\
\hline 2 & 30 & 70 \\
\hline 3 & 30 & 70 \\
\hline 4 & 30 & 70 \\
\hline 5 & 40 & 100 \\
\hline 6 & 50 & 90 \\
\hline 7 & 30 & 70 \\
\hline 8 & 40 & 70 \\
\hline 9 & 40 & 70 \\
\hline 10 & 50 & 90 \\
\hline 11 & 50 & 100 \\
\hline 12 & 20 & 90 \\
\hline 13 & 40 & 100 \\
\hline 14 & 40 & 60 \\
\hline 15 & 60 & 70 \\
\hline 16 & 20 & 90 \\
\hline 17 & 60 & 90 \\
\hline 18 & 50 & 80 \\
\hline 19 & 50 & 70 \\
\hline 20 & 20 & 70 \\
\hline 21 & 30 & 70 \\
\hline 22 & 60 & 100 \\
\hline 23 & 20 & 100 \\
\hline 24 & 30 & 90 \\
\hline 25 & 40 & 100 \\
\hline 26 & 40 & 80 \\
\hline 27 & 50 & 90 \\
\hline 28 & 30 & 70 \\
\hline Average & 39,2 & 82,5 \\
\hline
\end{tabular}


Based on the data, the average score of the initial test (pre-test) is 39.2 with the lowest value of 20 , and the highest value is 60 . While the average value of the final test (post-test) is 82.5 with the lowest value of 60 , and the highest value is 100 . The data is then calculated to find out the increase in value using the N-Gain formula as follows.

$$
\begin{gathered}
g=\frac{S \text { post }-S \text { pre }}{\text { S maks }-S \text { pre }} \\
g=\frac{82,5-39,2}{100-39,2} \\
g=\frac{43,3}{60,8} \\
g=0,712
\end{gathered}
$$

Based on the calculation, the gain value is 0.712 which means that the category is "High" ( $\mathrm{g} \geq$ 0.70). The results of these calculations are also presented in table 6 below.

\section{Table 9}

The calculation of the effectiveness test with N-Gain

\begin{tabular}{llll}
\hline No & Variable & Pre-test & Post-test \\
\hline 1 & Highest score & 60 & 100 \\
& Lowest score & Pre- & \\
2 & test score & 20 & 60 \\
3 & Average & 39,2 & 82,5 \\
Gain Value & 0,712 & \\
Categories & High & \\
\hline
\end{tabular}

Based on the entire data, it is implied that there is a significant improvement in the value of students after using the interactive learning multimedia. This is evidenced by an increase in scores on the final test (post-test). Therefore, it can be concluded that Simulation-Based Interactive Learning Multimedia for Natural Sciences Practicum in Grade VII Junior High School with Energy in Life Systems material proved to be effective with a high level of effectiveness. 


\section{Product Revisions}

Revision is a stage of improvement of a product developed based on the suggestions and improvements provided. Suggestions and improvements used as a reference in this revision stage are from media experts and material experts.

\section{Revision of media experts}

Revisions in terms of the media are based on suggestions and improvements given. The suggestions and improvements are as follows.

The first is the clarity of narration (instructions on the usage instructions page). Usage instructions that were originally in the form of video are replaced with text and images to make instructions clearer. This is considering that the media is in a computer laboratory room where the video's narrative sound might confuse the users since the video's sound on one user can collide.

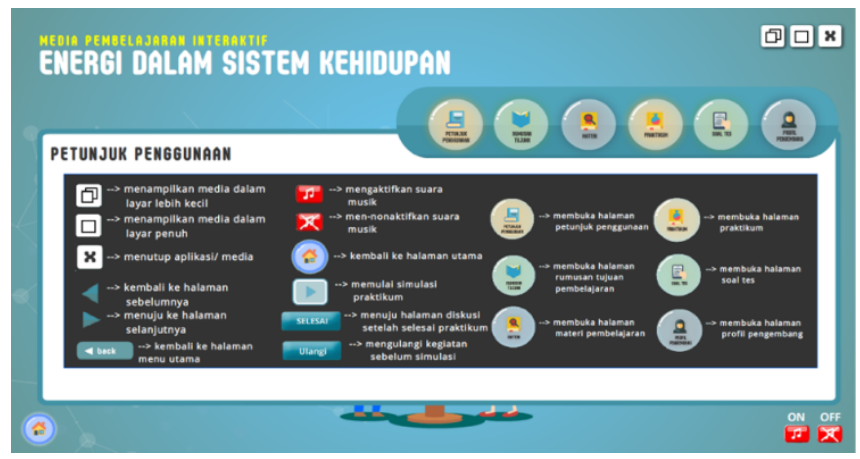

Figure 21. Changing the usage instructions to text and images

The second revision is the addition of confirmation page as feedback from the close / exit button. As suggested by media experts, the researchers added a confirmation page for the close / exit button so that when the button is clicked, a confirmation page will appear. It is presented in Figure 20. 


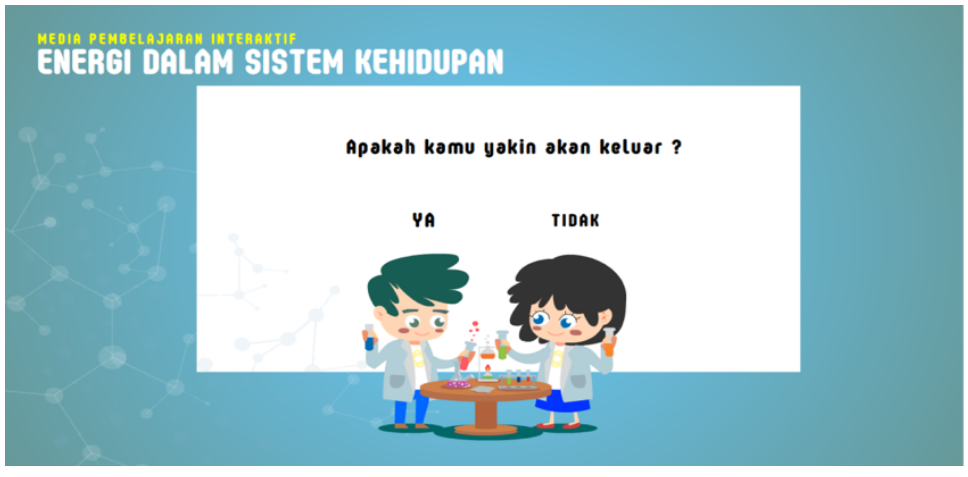

\section{Figure 22. Exit page after revision}

The next is revision of material experts. Revisions in terms of the materials are based on suggestions and improvements provided by material experts. The material experts validating the media stated that the simulation-based interactive learning multimedia for the Natural Sciences practicum was worth testing with some improvements. The suggestions and improvements include the affirmation of the concept of photosynthesis, where some less precise words might allow misconceptions. Furthermore, the instructions in the practicum section should be made more detailed and clearer so that they become more understandable.

\section{CONCLUSION AND SUGGESTIONS}

Some conclusions were obtained from the results of research and development of the simulation-based interactive learning multimedia for science practicums. The conclusions are extended as follows:

Firstly, a practicum is beneficial in science learning to provide a concrete manifestation of a topic. Therefore, teachers should be able to provide a real-like experiences during the learning process. Such experiences are expected to assist students to obtain deeper understanding about the topic. Moreover, as science is mostly abstract (invisible for the naked eye), the real-like experiences are considered very beneficial for those who lack of thinking abstractly.

Secondly, the simulation-based interactive learning multimedia for science labs were developed by using Macromedia Flash 8 . It was then packaged in the form of application programs in the format .exe which can be accessed through computer devices.

Thirdly, the test results of the alpha test by media experts obtained an average value in the "Feasible" category, whereas the average score by material experts was in the "Very Feasible" category. The beta test results by six (6) respondents obtained an average value with the 
category "Very Feasible". In addition, the developed interactive learning multimedia has proven to be effective in increasing students' analytical skills based on an average score of 39.2 for the initial test (pre-test) and 82.5 for the final test (post-test), so it was obtained the value of $\mathrm{N}$-gain of 0.712 with the category "High".

At last, it is hoped that teachers can later use the product to support the visualization of the topic. They are expected to be able to develop themselves in terms of using extensive kinds of media and materials that can assist students to get deeper understanding. In addition, local government as well as stakeholders are suggested to provide both material and moral support pertinent to the use of interactive learning multimedia through furnishing schools' facilities. Teacher cannot wish for a better learning environment which including technology integration, when there is no sufficient support of facilities (Taopan, L., L., Drajati, N., A., \& Sumardi, 2019). Further, more extensive trainings of the use of technology to assist learning process should be provided in order to help teachers to cope with the rapid development of science and technology.

\title{
Ortaokullarda Fotosentez ve Solunum Uygulaması için Simülasyon Temelli Etkileşimli Öğrenme
} Ortamları Geliştirme

\begin{abstract}
Özet
Uygulama, bir konunun somut olarak anlaşılmasını sağlamak için fen öğretiminde faydalıdır. Bu çalışma, öğrencilerin pratiğine yardımcı olmak için simülasyon tabanlı etkileşimli bir öğrenme ortamı geliştirmeyi amaçlamaktadır. Geliştirilen ürün, canlılarda enerjiye odaklanan hücre metabolizması sürecini anlama konusu için geliştirilmiştir. Çalışmada, araştırma ve geliştirme süreci bağlamında; analiz, tasarım, geliştirme, uygulama ve değerlendirme modeli kullanılmıştır. Geliştirme sürecinde hem ürün testi hem de kullanıcıların yanıt testleri kullanılmıştır. Ürün etkisini ortaya çıkarmak için, öğrencilerin ön test ve son test sonuçları analiz edilmiş ve, Macromedia Flash 8 kullanılarak ürün geliştirilmiştir. Analiz sonuçları, geliştirilen ürünün "uygulanabilir" ve "çok uygulanabilir" olduğunu göstermiştir. Ayrıca, ilk test için 39.2 ve son test için 82.5 ortalama değerine dayanarak, yüksek düzeyde bir değer elde edilmiştir. Bu nedenle, geliştirilen etkileşimli öğrenme ortamının ortaokullarda öğrencilerin Fen Bilgisi dersi için öğrenme materyalleri olarak analitik becerilerini artırmada etkili olduğu kanıtlanmıştır.
\end{abstract}

Anahtar kelimeler: ADDIE, analitik beceriler, hücre metabolizması, etkileşimli ortam, fen bilgisi öğretimi

\begin{abstract}
About the Authors
Putri

Putri is a graduate student at State University of Yogyakarta, Indonesia, Department of Educational Technology. She has continued her academic life as a graduate student in 2018. Her areas of interest are educational technology, media development, and teaching materials.
\end{abstract}

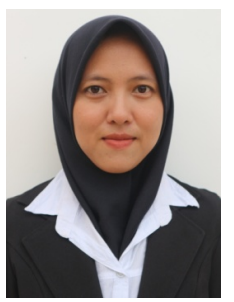




\section{Herminarto Sofyan}

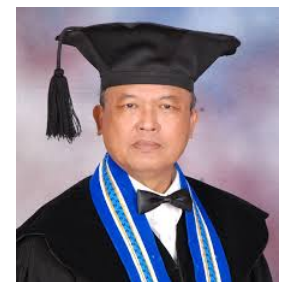

Herminarto Sofyan is a lecturer at State University of Yogyakarta, Department of Educational Technology. His areas of interest are media development, teaching materials, and educational technology.

Email: herminsuny@gmail.com

\section{REFERENCES}

Allen, W.C. (2006). Overview and evolution of the ADDIE training system. Advances in Developing Human Resources, No. 8, pp. 430-441.

Altun, E., Baris. D., Burk. Alev. A., Ilker. C. (2009). Developing an interactive virtual chemistry laboratory enrich with constructivist learning activities for secondary school: Procedia social and behavioral sciences, 1.

Arifah, Isnaeni. Maftukhin \& Fatmaryanti, S.D. (2014). Pengembangan buku petunjuk praktikum berbasis guided inquiry untuk mengoptimalkan hands on mahasiswa semester II program studi pendidikan fisika universitas muhammadiyah purworejo tahun akademik 2013/2014. Jurnal Pendidikan Fisika, 5 (1): 24-28.

Arsyad, Azhar. (2011). Media pembelajaran. Jakarta: Rajawali Press.

Darmawan, Deni. (2012). Teknologi pembelajaran edisi kedua. Bandung: Remaja Rosdakarya.

Dick, W., \& Carey, L. 1996. The systematic design of instruction (4th ed.). New York: Harper Collins College Publishers

Hotimah \& Ali, M. (2017). Pengembangan multimedia interaktif IPA untuk meningkatkan pemahaman siswa pada materi mikroorganisme SMP. Jurnal Inovasi Teknologi Pendidikan, 4 (2): 212.

Isaac, S., \& Michael, W. B. (1995). Handbook in research and evaluation: A collection of principles, methods, and strategies useful in the planning, design, and evaluation of studies in education and the behavioral sciences ( $3^{\text {rd }}$ ed.). San Diego, CA, US: EdITS Publishers. 
Januszewski, A., \& Molenda, M. (2008). Educational Technology: A definition with commentary. New York: Routledge.

Larasati, D., S., \& Sukisno, M. (2014). Penggunaan media simulasi berbasis teknologi informasi dalam pembelajaran fisika pada siswa lintas minat di SMA Negeri 3

Mulyatiningsih, Endang. (2012). Metode penelitian terapan bidang pendidikan. Bandung: Alfabeta.

Nasution. (2005). Teknologi pendidikan. Jakarta: Bumi Aksara.

Rusman, Kurniawan \& Riyana. (2011). Pembelajaran berbasis teknologi informasi dan komunikasi mengembangkan profesionalisme guru. Jakarta: Raja Grafindo Persada.

Seels, Barbara B. \& Richey, Rita C. (1994). Teknologi pembelajaran: definisi dan kawasannya. Jakarta: Unit Percetakan Universitas Negeri Jakarta.

Siregar, et al. (2019). EFL teachers' perceived challenges in implementing the 21 st-century pedagogical competence: a case study. International Journal of Education and Social Science Research. (2) 6: 67-77.

Siregar, et al. (2020). The effective $21^{\text {st }}$-century pedagogical competence as perceived by preservice english teachers. Pedagogy Journal of English Language Teaching, (8) 1: 1-12.

Sugiyono. (2011). Metode Penelitian Kuantitatif, Kualitatif dan R\&D. Bandung: Afabeta.

Sundayana, R. (2014). Statistika Penelitian Pendidikan. Bandung: Wacana Prima.

Surjono, Herman.D. (2017). Multimedia pembelajaran interaktif: konsep dan pengembangan, edisi pertama. Yogyakarta: UNY Press.

Susilowati. (2014). IPA dan pembelajarannya. Yogyakarta: UNY Press.

Sutopo, Ariesto Hadi. (2003). Multimedia interaktif dengan flash. Yogyakarta: Graha Ilmu.

Taopan, L. L., Drajati, N. A., \& Sumardi. (2019). Discovering the teacher' s beliefs in TPACK framework for teaching English in high school. Indonesian Journal of Informatics Education, 3(1).

Taopan, L. L., Drajati, N. A., \& Sumardi. (2020). TPACK Framework: Challenges and Opportunities in EFL Classrooms. Research and Innovation in Language Learning, 3 (1)(January), 1-22. 10 Retrieved from 


\section{http://jurnal.unswagati.ac.id/index.php/RILL\%0ATPACK}

Toharudin, Uus. (2011). Membangun literasi sains peserta didik. Bandung: Humaniora

Trianto, (2010). Model pembelajaran terpadu. Jakarta: Bumi Aksara.

Warsita, Bambang. (2008). Teknologi pembelajaran (landasan dan aplikasinya). Jakarta: Rhineka Cipta.

Widodo, W., Fida, R., Siti, N. (2016). Ilmu pengetahuan alam: edisi revisi untuk SMP/MTs kelas VII semester 1. Jakarta: Kementerian Pendidikan dan Kebudayaan. 